DOI 10.37882/2223-2982.2020.08.19

\title{
СЕМАНТИЧЕСКИЙ И ЭТИМОЛОГИЧЕСКИЙ АСПЕКТ ИЗУЧЕНИЯ НЕОЛОГИЗМОВ - ГЛАГОЛОВ В СОВРЕМЕННОМ РУССКОМ ЯЗЫКЕ
}

\section{SEMANTIC AND ETHYMOLOGICAL ASPECT OF THE STUDY OF NEOLOGISM-VERBS IN MODERN RUSSIAN LANGUAGE}

O. Kuzina

Summary: This article discusses the problems of interpreting language as a social developing phenomenon, replenished with new words and meanings. The content of the article traces a number of difficulties in understanding neologisms, which are designed to solve the problem of interpretation and word formation of neologisms-verbs in modern Russian. On the example of the characteristics of neologisms-verbs, a semantic-stylistic and derivational analysis of new words was carried out. The research is based on the "Explanatory Dictionary of New Words and Meanings of the Russian Language" by L.P. Katlinskaya.

Keywords: neologisms, semantics, etymology, word formation, lexical derivation, morphemics, word-formation types and models.

\author{
Кузина Ольга Васильевна \\ к.ф.н., доцент, ФГБОУ ВО Гжельский государственный \\ университет (ГГУ) \\ kuzina85@bk.ru
}

Аннотация: В данной статье рассмотрены проблемы толкования языка как социального развивающегося явления, пополняющегося новыми словами и значениями. В содержании статьи прослеживается ряд трудностей в осмыслении неологизмов, которые призваны решить проблему толкования и словообразования неологизмов-глаголов в современном русском языке. На примере характеристики неологизмов-глаголов был проведен семантико-стилистический и словообразовательный анализ новых слов. Базисом исследования стал «Толковый словарь новых слов и значений русского языка» Л.П. Катлинской.

Ключевые слова: неологизмы, семантика, этимология, словообразование, лексическая деривация, морфемика, словообразовательные типы и модели.

сти социальных явлений и процессов, кроме того, выявляют их социальную значимость;

- лексикографическая фиксация - этот критерий указывает на различия между неологизмами и окказионализмами. Окказионализмы не фиксируются в словарях: «окказиональные слова, фигурирующие в словоупотреблении только одного или нескольких лиц, включению в словарь не подлежат: они засоряют его, создавая неправильное представление о словарном составе языка» $[6,4]$.

Индивидуальноавторские образования следует относить к окказионализмам, поэтому следует учитывать ряд вышеуказанных критериев при разграничении понятий «неологизм» и «окказионализм». В отличие от неологизмов, являющихся достоянием общенародного языка, окказионализмы - это слова, созданные тем или иным автором (при этом одни из них могут войти в языковую систему, а другие - не имеют такой возможности).

Классификация способов словообразования с точки зрения лексической деривации была впервые предложена выдающимся филологом В. В. Виноградовым. Согласно его классификации, все способы лексической деривации делятся на 2 группы: неморфологические (лексико-семантический, морфолого-синтаксический, лексико-синтаксический) и морфологические способы (аффиксация, безаффиксный способ, сложение основ, аббревиация). 
Лингвист Н.С. Валгина в своих научных трудах тоже подаёт классификацию способов лексической деривации, среди них: лексико-семантический, лексико-синтаксический, морфолого-синтаксический и морфологический $[2,37]$.

Как видим, обе классификации схожи, но главным отличием классификации Н.С. Валгиной является то, что автор не делит способы на две группы, а представляет каждый отдельно. Характеристика В. В. Виноградова подаёт более подробную и чёткую классификацию способов словообразования. Словообразование связано с другими уровнями языковой системы - фонологией, морфологией, синтаксисом и, конечно же, лексикой, поскольку результатом словообразовательных процессов является именно появление новых слов. Новые слова появляются в русском языке разными путями: одни приходят из других языков, другие приобретают вторичные значения, третьи же поддаются словообразовательной деривации $[1,61]$.

Продуктивность форм словообразования имеет связь с процессами развития словарного состава языка (которые отображают изменения в жизни общества). Наряду с продуктивными словообразовательными типами в языке наличествуют непродуктивные (к ним относят словообразовательные типы, которые насчитывают в своем составе некоторое количество слов, однако новыми уже не пополняются).

Словообразовательные типы, находящиеся в языковой системе, обладают определенной степенью системной продуктивности. Степень продуктивности разных словообразовательных типов и моделей неодинакова. Можно утверждать, что если в языке есть определенная модель, реализованная всего лишь даже одним словом, ее уже следует включить в систему языка.

Говоря о словообразовательных моделях, следует отметить, что большинство лингвистов, освещавших в своих работах эту тему, уделяли большое внимание продуктивности / непродуктивности и регулярности / нерегулярности. Отталкиваясь от научных трудов Н.В. Крушевского, Г.О. Винокура, В.В. Лопатина и В.В. Виноградова, дадим определение продуктивности / непродуктивности и регулярности / нерегулярности словообразовательных типов:

- регулярные словообразовательные типы - это такие формальные и семантические многократно повторяющейся модели, по которым построены производные слова;

- нерегулярные словообразовательные типы - это единичные образования, среди которых могут быть отступления от общей формальной или семантической модели;

- продуктивные словообразовательные типы - это модели, по которым образуются новые слова в данное время. отмечено, что в современном разговорном русском языке часто используются существительные, образованные от существительных;

- непродуктивные словообразовательные типы это модели, по которым в данное время не создаются новые слова.

Значит, если в языке есть определенная модель, пусть реализованная пока всего только одним словом, ее уже необходимо включить в языковую систему. Если словообразовательные типы находятся в системе языка, то они обладают определенной степенью системной продуктивности.

Изучая вопрос о семантическом разнообразии неологизмов-глаголов в современном русском языке, перед нами встала необходимость классифицировать их по тематическим группам и подгруппам. С этой целью нами была создана картотека на материале «Толкового словаря новых слов и значений русского языка» Л.П. Катлинской. Новые слова весьма разнообразны с точки зрения их деривационной семантики, их словообразовательные значения фиксируют разные аспекты действительности (сферы быта, социума, финансовой деятельности, бизнеса, науки, техники, искусства, средств массовой информации (СМИ) и др.).

Наиболее многочисленной оказалась группа глаголов социальной сферы (быта) - 27 лексических единиц (достать (в значении надоесть), отследить, парковать, грузить, гнобить).

Второй по численности тематической группой является группа глаголов финансовой сферы и бизнеса - 17 слов: акционироваться, вкладываться. В данной тематической группе слов были выделены такие лексико-семантические подгруппы: сфера финансовой деятельности и банковского дела (обналичить, индексировать) и сфера бизнеса и деловых отношений (банкротить, демонополизирвать).

Следующей по количеству слов оказалась группа глаголов сферы информационно-коммуникационных технологий. Эта группа насчитывает 8 слов в словаре: заnuсать, отксерить.

На четвертой позиции разместились две тематические группы - глаголы политической сферы (заветировать, деnymamcmвовать, лоббировать) и глаголы сферы СМИ (раскрутить, страртовать). К каждой из них относится по 11 слов из анализируемого словаря.

Следующими по количеству слов оказались сразу четыре тематические группы: глаголы сферы искусства 
(карнавалить, портретировать, презентоваться), научно-технической (клонировать, профессорствовать), обще-профессиональной (вахтовать, сработать, адаптироваться) и узкопрофессиональной сферы (кронировать, шишковать, лочировать). К каждой из вышеперечисленных групп относится по 7 слов словаря.

Тематические группы глаголов сферы психологии (грузиться, расслабиться) и философии (отеплять, рабствовать), а также глаголы медицинской сферы (глючить, загипсовать) представлены в малом количестве. Каждая из этих групп состоит из 4 слов. Немногочисленной оказалась группа глаголов экстрасенсорной сферы. К этой тематической группе относится всего 2 слова: ведьмачить и демонизировать.

Следующим этапом работы над словарным материалом стала классификация лексем по способам словообразования. Из 2000 единиц языкового материала словаря было отобрано 113 неологизмов-глаголов. Так, наша картотека насчитывает 61 слово (53,9\%), образованное лексико-семантическим способом и 52 (46,02\%) - морфологическим. К лексико-семантическому способу словообразования относятся те слова, которые уже были в русском языке, но приобрели новые значения. По данным нашей картотеки, большее количество нео- логизмов-глаголов образовано именно этим способом. Слова, образованные морфологическими способами, составили меньше половины отобранного языкового материала.

Так, характеристика лексических единиц с точки зрения словообразования говорит о том, что большая часть неологизмов образована лексико-семантическим способом, а морфологические способы словообразования представлены в довольно малом количестве. В ходе работы было выявлено продуктивные и непродуктивные словообразовательные способы и типы.

Предпринятый метод работы позволил сделать вывод о том, что лексико-семантическим способом образовано больше половины отобранного материала, а морфологические способы словообразования представлены в довольно малом количестве. В ходе работы было выявлено продуктивные и непродуктивные словообразовательные способы и типы. К продуктивным способам словообразования можно отнести суффиксацию, префиксально-суффиксальный и префиксальный способы. Суффиксально-постфиксальный, постфиксальный способ, а также способ словообразования, при котором слово образуется путем одновременного присоединения аффиксов являются непродуктивными.

\section{ЛИТЕРАТУРА}

1. Булавина Н.В. Понятие «новое слово» в современной лингвистике / Н.В. Булавина // Вестник КГУ им. Н.А. Некрасова. - 2012. - № 5. - С. 61-62.

2. Валгина Н.С. Современный русский язык: учебник / Н.С. Валгина, Д.Э. Розенталь, М.И. Фомина ; под ред. Н.С. Валгиной. - 6-е изд., перераб. и доп. - М. : Логос, 2002. $-528 \mathrm{c}$.

3. Москалёва М.В. Неологизмы и проблема их изучения в современном русском языке / М.В. Москалёва // Известия Российского государственного педагогического университета им. А. И. Герцена. - 2008. - № 80. - С.246-249.

4. Розенталь Д.Э. Современный русский язык / Д.Э. Розенталь, И.Б. Голуб, М.А. Теленкова. - 11е изд. - М. : Айрис-пресс, 2010. - 448 с. - (0т А до Я).

5. Толковый словарь новых слов и значений русского языка: около 2000 слов / Л.П. Катлинская. - М. : АСТ: Астрель, 2008. - 380 с.

6. Фельдман Н.И. Окказиональные слова и лексикография / Н.И. Фельдман // Вопросы языкознания. - 1957. - № 4. - С. 4-12.

7. Шанский Н.М. Современный русский язык. В 3-х. ч. Ч. 2. Словообразование. Морфология / Н.М. Шанский, А.Н. Тихонов. - М. : Просвещение, 1987. - 254 с.

(с) Кузина Ольга Васильевна (kuzina85@bk.ru). 